\title{
Analysis of Link and Match Policies in Improving Work Readiness of Vocational Student in West Java
}

\author{
Agus Rahayu*, L.A. Wibowo, S.Sulastri \\ Universitas Pendidikan Indonesia \\ Bandung, Indonesia \\ *agusrahayu@upi.edu
}

\begin{abstract}
This study aims to analyze the link and match policy issued by the Minister of Industry of the Republic of Indonesia number 03 / M-IND / PER / 1/2017 concerning Guidelines for Development and Competency-based Vocational High Schools that do link and match in the industry in order to improve vocational graduates' job readiness in West java. The method used in this study is qualitative with a case study approach that aims to analyze intensively about the implementation of the link and match policy in West Java and to what extent the increasing readiness of vocational students work in West Java. The results in this study illustrate that the link and match policy has been implemented including the preparation of projections for the development of types, competencies and industrial locations, especially those related to vocational graduates; increasing cooperation with the business community to provide wider access for vocational students to carry out field work practices for educators and education, to encourage industries to provide support in the development of teaching factories and infrastructure, and to accelerate the completion of work ability formulations that cover aspects of knowledge, skills and attitude that is relevant to the implementation of duties and terms of office set in accordance with the provisions of the laws and regulations that apply in the industrial field. The overall strategy carried out has increased the number of vocational students' work readiness in West Java.
\end{abstract}

Keywords-Link and Match Policies; Work Readiness; Vocational Students

\section{INTRODUCTION}

One of the factors that determine the success of development in the economic field is human resources. Economic growth is not solely dependent on the amount of human resources, but more on their efficiency [1]. Human resources are at the core of a nation's competitiveness. One that is competitive and skilled is one that can be produced from quality vocational education that is relevant to the demands of a dynamic workforce. Vocational High School (SMK) is one of the vocational education institutions that prepares skilled workers ready for work.

The existence of SMKs in Indonesia in preparing skilled middle-level workforce still needs to be improved. Not all vocational graduates can meet the demands of employment according to their specialization. This is because there is a gap between the skills possessed by SMK graduates and the skills needed in the workforce. In addition to skills, vocational students have not fully had work readiness, because there are still many graduates who are still unemployed. Based on data from the Central Statistics bureau, the open unemployment rate (TPT) up to February 2017 was 5.33\%. This figure fell from the previous period, which was equal to $5.50 \%$. However, the unemployment rate is still dominated by graduates of Vocational High Schools.

The high unemployment rate can be explained from various aspects, one of which is the existence of a mismatch between the supply of labour and the demand of the business / industry. Educational mismatch occurs because of the heterogeneity of workers' abilities in the same educational qualifications. Many previous studies have attempted to test the occurrence of mismatch between competencies mastered by graduates and industry. Some researchers conducted a mismatch study seen from the educational approach [2], [3], [4], [5]. While most researchers examine how the role of the company as the first formal experience for graduates [6], [7], [8], [9]

One of the government's strategies in revitalizing SMKs in Indonesia is to issue a link and match policy between Vocational Schools and the industrial world. The aim of the application of link and match in vocational education is to bring the supply and demand of quality human resources closer, especially those related to the quality of employment where the world of education acts as a provider of human resources to the world of work and the community or parties that need them. Through this collaboration, optimal outputs and outcomes can be obtained. One of the policies issued by the government regarding the link and match of Vocational School with the industry is the regulation of the Ministry of Industry of the Republic of Indonesia Minister of Industry Regulation No. 3 / M-IND / PER / 1/2017 concerning guidance and development of competency-based vocational secondary schools that link and match with the industry. With the existence of this policy, it is expected that there will be synergy between the government, the industrial world and the school in 


\section{B. Concepts of the Business World and the World of Industry}

order to prepare vocational graduates who are ready to work. Based on the description above, it is necessary to analyze a link and match policy of Vocational School with industry in increasing vocational readiness for vocational graduates.

\section{A. Link and Match Concept}

One of the educational policies through Vocational Schools is link and match, namely the existence of 1) the relationship between educational programs provided in schools with broad community needs, and 2) the existence or compatibility between educational programs and products in schools with community needs [10]. The purpose of the application of link and match in vocational education is to bring the supply and demand of quality human resources closer, especially those related to the quality of employment where the world of education acts as a provider of human resources to the world of work and the community or parties that need them. Through this collaboration, optimal outputs and outcomes can be obtained, namely HR capable of thinking critically, creatively and innovatively in accordance with the needs of the community and the job market.

Link and Match can be done through two approaches, namely the social approach and the employment approach.

The social approach is an approach that is based on the needs of the community at this time. This approach focuses on the purpose of education and on equal opportunity in getting education [11]. The social approach is a traditional approach to the development of education by providing institutions and facilities to meet the pressure of pressure to incorporate schools and allow the opportunity to freely give students and parents [12]. An example of implementing this approach is the application of a dual system through the Link and Match policy.

Furthermore in this approach, there are several weaknesses including the following:

1) This approach ignores the problem of allocation on a national scale, and vaguely does not question the magnitude of the educational resources needed by the arena to assume that the best use of educational resources is for the entire Indonesian people.

2) This approach ignores manpower planning that is needed in the community so that it can produce graduates that are actually less needed by the community.

3) This approach tends to only answer educational equity so that the quantity takes precedence over the quality [13].

Meanwhile, the next is Employment Approach. In this employment approach, educational activities are directed towards efforts to meet the national need for labor in the early stages of development, of course, requiring many workers from all levels and in various types of expertise.

In this situation most countries expect education to prepare and produce skilled labor for development, both in the agricultural, trade, industrial and so on [14]. For this reason, educational planners must try to estimate the amount and quality of labor needed by each national development activity.
The business world and the industrial world are terms relating to other companies or agencies that are related to selfbinding employment and are willing to cooperate with educational and training institutions [15].

\section{The Concept of Work Readiness}

Work readiness focuses on personal traits, such as the nature of the worker and the defense mechanism needed, not only to get a job but also more than that is to maintain a job [16]. Overall aspects of work readiness consist of [17]:

- Skills, abilities needed to carry out several tasks that develop from the results of training and experience gained. Practical skills, interpersonal and intrapersonal skills, creative and innovative, critical thinking and capable of solving problems, working together can adjust, and communication skills.

- Science, which makes education as a base theoretically so as to have the ability to become experts in accordance with their fields. As a graduate candidate must have extensive knowledge and insight.

- Understanding, a person's ability to understand or understand something that has been known and remembered, so that his work can be done and obtained satisfaction while knowing what he wants. Understand the knowledge that has been learned, determine, estimate and prepare for what will happen and be able to make decisions.

- Attributes of personality, encourage someone to bring up the potential that exists within themselves. Personality in the undergraduate sphere is work ethics, responsibility, business spirit, time management, having the ability to think critically, communicate and be able to work together.

\section{Methodology}

This study is a qualitative by using a case study research approach. Case studies are included in descriptive research, namely to get an overview of cases that are being observed and analyzed carefully. This analysis is carried out on government policies related to link and match of Vocational Schools with the industrial world especially its implementation in West Java province. The data taken in this study came from various sources collected through the Forum Group Discussion activities and in-depth interviews with policy makers who are related to the link and match of Vocational Schools with the industrial world. The number of informants in this study were 21 people consisting of 9 people from government agencies related to link and match policies or related to education in vocational schools as well as 12 school principals or vice principals in the field of industrial relations in West Java.

\section{RESULTS AND DISCUSSION}

Indonesia has six strategic issues which are the priority of Vocational revitalization, namely alignment and updating of the curriculum; learning innovation; fulfillment and improvement of the professionalism of teachers and education 


\section{CONCLUSION}

personnel; and school partnerships with business / industry and universities; standardization of main facilities and infrastructure; and institutional arrangement / management.

The violation and updating of the Vocational curriculum prioritizes the suitability of technological development and conformity to the real needs of business and industry. The government has also supported industrial cooperation programs by involving the role of vocational teachers through a dual expertise program supported by an industry internship program for productive teachers and visiting teachers from the industry. Increased employment of vocational graduates will be encouraged through the provision of competency certification of graduates through the One Party Professional Certification Institution (LSP-P1). In addition, the expansion of teaching factories in Vocational Schools is designed to encourage innovation and productivity of SMK graduates.

Vocational education policy is a government effort to direct change, limit choices, guarantee (benefit, justice, and certainty), overcome disputes, and control the behavior of individuals, institutions, and sub-administrations in order to achieve national education goals. Vocational education policy is a response to the "cause" and the results of the policy in the form of "consequences" that run continuously. The implementation of policies related to the link and match of Vocational Schools with the industrial world, the Ministry of Industry composes several strategies including:

- Developing projections for the development of types, competencies (job titles) and location of industries especially those related to vocational graduates

- Planning for the industrial sector labor needs for 20152035 has been prepared based on the field and level of expertise according to the industry subsector and its development area

- Enhancing cooperation with the business world to provide wider access for senior high school students to carry out field work practices and apprenticeship programs for educators and education

- Alignment of curriculum, syllabus and learning module has been carried out for 34 skill competencies, socialization of the results of alignment and work program preparation

- Encouraging industry to provide support in developing teaching factories and infrastructure

- Speeding up the completion of Indonesian National Work Competency Standards in the industrial sector.
Research has succeeded in analyzing the role of the government in implementing link and match policies related to guidance on guidance and development of competency-based vocational secondary schools that link and match industries including formulation and adoption, implementation, and evaluation policy. From the results of the study identified several main problems related to the link and match of Vocational Schools with the industrial world, one of which is curriculum designation.

\section{REFERENCES}

[1] ML Jhingan, Ekonomi Pembangunan dan Perencanaan, Jakarta Rajawali, Press, 2004.

[2] Sala, Guillem. "Approaches to skills mismatch in the labour market: a literature review." Papers: revista de sociologia 96, no. 4, 1025-1045, 2011

[3] Hanafi, Ivan. "Re-orientasi keterampilan kerja lulusan pendidikan kejuruan." Jurnal Pendidikan Vokasi 2, no. 1, 2012.

[4] Amador, María \& Vila, Luis, "Education and skill mismatches: Wage and job satisfaction consequences", International Journal of Manpower. 34. 10.1108/IJM-05-2013-0116, 2013

[5] Sattinger, M., "Assignment models of the distribution of earnings", Journal of Economic Literature, Vol. XXXI, 1993

[6] Baker, Lord of Dorking CH, The Skills Mismatch. EDGE Foundation, 2014

[7] Santos, Marcelo Serra. "Education, educational mismatch, and wage inequality: evidence for different european countries." PhD diss., 2012.

[8] Dobbs, Richard, and Anu Madgavkar. "The world at work: Matching skills and jobs in Asia." Prospects 44, no. 2 : 197-210, 2014.

[9] Jonbekova, Dilrabo. "University graduates' skills mismatches in central Asia: Employers' perspectives from Post-Soviet Tajikistan." European Education 47, no. 2 : 169-184, 2015

[10] W. Djojonegoro, "Pengembangan Sumber Daya Manusia Melalu Sekolah Menengah Kejuruan (SMK), Jakarta:PT Jayakarta Agung Offset, 1998

[11] H. Usman, "Manajemen, Teori, Praktik, dan Riset Pendidikan", Jakarta:Bumi Aksara, 2006

[12] I. Djumberansyah, "Perencanaan Pendidikan", Karya Abditama, 1995

[13] Saud, Udin Syaefuddin, "Pembelajaran Terpadu”, Bandung:UPI Press, 2006

[14] Enoch, Jusuf, "Dasar-Dasar Perencanaan Pendidikan”, Jakarta:Bumi Aksara, 1992.

[15] Wayong, A.D.Ch, "Relevansi Pendidikan Sistem Ganda pada Sekolah Kejuruan dengan Kebutuhan Dunia Kerja”, Seminar Internasional, ISSN 1907-2066, Asosiasi Pendidikan Teknologi dan Kejuruan Indonesia. Sulawesi Utara:UNIMA, 2010

[16] R. Brady, "Kesiapan Kerja bagi Inventaris Administrator". Jakarta : Akasia, 2009

[17] Pool, K.D and Sewell, P, "The Key to Employability: Developing a Practical Model of Graduate Employability", Education and Training Journal, 277-289, 2007. 